\title{
Relationship Between Stock Market Conditions and Investors Reactions: Evidence from Nigerian Stock Market
}

\author{
Ifeoma Patricia Osamor ${ }^{1}$, Edwin Chukwudozie Anene ${ }^{2}$, Qudus Ayotunde Saka ${ }^{1}$ \\ ${ }^{1}$ Department of Accounting, Lagos State University, Ojo, Nigeria \\ ${ }^{2}$ Department of Management and Accounting, Ladoke Akintola University of Technology, Ogbomoso, Nigeria
}

Email address:

ifyposamor@gmail.com (I. P. Osamor)

\section{To cite this article:}

Ifeoma Patricia Osamor, Edwin Chukwudozie Anene, Qudus Ayotunde Saka. Relationship Between Stock Market Conditions and Investors Reactions: Evidence from Nigerian Stock Market. International Journal of Finance and Banking Research. Vol. 5, No. 6, 2019 , pp. 140-144. doi: $10.11648 /$ j.jifbr.20190506.12

Received: August 6; Accepted: October 12, 2019; Published: November 5, 2019

\begin{abstract}
In the stock market, investors are regarded as rational being, but during the different market conditions, investors tend to react in an irrational manner which could lead to loss of investment. This prompted the investigation into the relationship between stock market conditions and investors' reaction in Nigerian stock market. Primary data was used to investigate investors' reaction towards stock market conditions and the data were sourced via a structured questionnaire from two hundred and twenty-one (221) registered dealing members in Lagos State, out of which only one hundred and seventyeight (178) responded. The study employed descriptive statistics to analyse the responses from the questionnaire, while Chisquare $\left(\chi^{2}\right)$ was used to determine if stock market conditions had any relationship with investors' reactions. The results of the study showed that there is a relationship between stock market conditions and investors' reactions in Nigerian stock market. This implied that when the different market conditions occurred, they influenced investors' decision on whether to buy, sell or hold on to a stock. The study therefore recommended that the influence of market conditions on investors' reactions should be put in check by investors because immediate reaction to every conditions that affect the market could lead to massive loss of investments.
\end{abstract}

Keywords: Stock Market Conditions, Investors’ Reactions, Herding Behaviour, Nigerian Stock Market

\section{Introduction}

What goes on in the mind of an investor is a mystery since no human mind can be predicted with certainty. During the different market conditions in the stock market coupled with external forces, investors have a vital decision to make with regards to whether to buy, sell or hold on to a particular stock. Many investors are always troubled with such decision because no rational human being wants to make a loss. In the stock market, investors are regarded as rational human being who make investment decisions based on risk and the associated returns from that investment.

Traditional finance argues that people are rational and they think rationally when making any decision or passing any judgments. Behavioural finance on other hand argues that in many cases our emotions affect our decisions and due to those emotions and psychological influences people make irrational decisions [9]. According to the 'Prospect Theory' of Kahneman and Tversky, it states that decisions are not always optimal, it is the willingness to take risk that determine the way decisions are made [10], but Ouarda, Abdelfatteh and Olivero suggested that it is important not to place too much concentration on investors and their rationality only, but also to introduce a variable of irrationality into the prospect theory in order to show that it is not only the willingness to take risk that determines the way decisions are made, it could also be as a result of herding behaviour [16].

Herding behaviour is often used in literature to describe the co-movement of members in a group without a planned direction [11]. The mimicking tendency of investors termed as herding results in investors buying and selling same or similar stocks in large numbers over a period of time [8]. It is a way of imitating how the other person buys or sells shares and implementing that in one's portfolio in order to feel more 
secure. Most investors herd based on information, reputation or compensation (rational herding), while other investors imitate the action of others rather than trusting their own assessment of the situation. In other words, when investors herd, they show a willingness to downplay the importance of their own information and evaluation in favour of the aggregate market consensus [22]. Influence of the different market conditions on investors reactions is an issue which could affect investment decision and this had not been considered by researchers $[7,14,15,25]$. Therefore, this study evaluates the relationship between market conditions and investors' reactions in Nigerian stock market.

\section{Theoretical and Empirical Review}

\subsection{Theoretical Review}

This study is anchored on two major theories of investors' reactions in the stock market. The first theory is the prospect theory, while the second is the heuristics theory.

\subsubsection{The Prospect Theory}

Prospect theory was proposed by Kahneman and Tversky and it states that investors have an irrational tendency to be less willing to gamble with profits than with losses [14]. It was suggested that the prospect theory is a world in which a person's view of the world is limited by the information that is available at a given moment and therefore the decisions a person makes may not be consistent and logical ([10] as cited in [5]).

The Prospect theory shows that decisions are not always optimal, it is the willingness to take risks which is influenced by the way choices are framed. The theory shows that investors' decisions are different depending on the way the choices are framed, whether as a loss or gain. This happens because people dislike losses more than they like an equivalent gain [10]. As stated by Ngoc, the theory describes some states of mind affecting an individual's decisionmaking processes which include regret aversion, loss aversion and mental accounting ([14] as cited in [23]).

Regret is an emotional state an individual falls into when mistakes are made. Regret aversion is when investors avoid regret by refusing to sell decreasing shares and willing to sell increasing ones. Moreover, investors tend to be more regretful about holding losing stocks too long than selling winning ones too soon $([6,12])$. Loss aversion refers to the different level of mental penalty people have from a similar size of loss or gain [2]. Barberis and Thaler showed evidence that people are more distressed at the prospect of losses than they are pleased by equivalent gains [3]. Furthermore, a loss coming after prior gain is proved less painful than a loss arriving after a loss which seems to be more painful than usual [2]. Mental accounting is described as the process by which people think about and evaluate their financial transactions [2]. Mental accounting allows investors to organize their portfolio into separate accounts $[3,17]$.

\subsubsection{Heuristics Theory}

Heuristics is defined as the rules of thumb, which makes decision making easier, especially in complex and uncertain environments by reducing the complexity of assessing probabilities and predicting values to simpler judgments ([10] as cited in [14]). People do not think rationally or they do not have enough time to process all information to make any decision so that's why they often use heuristics to reach to final judgment [9]. Kahneman and Tversky categorized the factors belonging to heuristics as representativeness bias, availability bias, and anchoring.

Representativeness bias is defined as mental shortcut that has the tendency to irrationally attribute one characteristic to imply another ([10] as cited in [9]). AlKhars, Evangelopoulos, Pavur and Kulkarni stated that representativeness heuristic is also employed when subjects estimate the probability of a specific parameter of a sample [1].

Ngoc explained that availability bias happens when people make use of easily available information excessively [14]. In stock trading, availability bias manifest itself through the preference of investing in local companies which investors are familiar with or easily obtain information, despite the fundamental principles of diversification in portfolio management for optimization [23].

Anchoring was defined by Kahneman and Tversky as a phenomena used in the situation when people use some initial values to make estimation, which are biased toward the initial ones as different starting points yield different estimates [14]. Anchoring occurs in the stock market when the range for the price of a stock is fixed by current observations. When considering the sale of a stock, investors refer to the initial purchase price of the stock, therefore, today prices are often determined by past prices which could result to under-reaction to unexpected changes. Anchoring is related to representativeness as it also reflects that people often focus on recent experience and tend to be more optimistic when the market rises and more pessimistic when the market falls [23].

\subsection{Empirical Review}

$\mathrm{Oh}$ and Kim conducted a study on effects of investors reactions to firm characteristics measured by price-to-book (PB) ratio, free cash flow (FCF), and variability of daily stock return (VDR) in the stock market. 5,000 news relating to IT announcement data were gathered from Lexis-Nexis for a period of six months between July 1999 to December 1999 and daily stock returns from University of Chicago's Center for Research in Security Prices. Their study discovered that cumulative abnormal returns, price-to-book ratio, and variability of daily stock returns significantly affect the investors' reaction to IT investment announcements [15].

The study carried out by Mahmoudi, Shirkavand, and Salari on 'How do investors react to the earnings announcements? in Tehran stock exchange for a period of eight years, that is 2003 to 2010. Earnings Per Share (EPS) announcements were used and the results showed that 
investors react significantly to the financial statement reports by under-reacting to both positive and negative earnings announcements changes [13].

Ngoc examined the behavioral factors influencing the decision making of individual investors in Ho Chi Minh City securities companies, Vietnam. Deductive approach was adopted using five behavioral elements such as herding, market, prospect, overconfidence-gamble's fallacy, and anchoring-ability bias. Data was sourced from 188 individual investors and the study discovered that over-confidence, loss aversion, regret aversion and anchoring have moderate impact on investors' reactions, while mental accounting had the highest impact on investors' decision [14].

Folkinshteyn, Meric and Meric conducted a research on investors' reaction in stock market crashes and post-crash market reversals using data from five major stock market crashes during the 1987-2008 period. They find some evidence that some investors overreacted in all the five stock market crashes. They find that high beta stocks lose more value in crashes and gain more value in post-crash market reversals relative to low beta stocks. They further find out that smaller firms and those with a low market-to-book ratio lose more value in stock market crashes [7].

Irshad, Badshah and Hakam studied the effect of one of the factors of heuristic theory (representativeness bias) on investment decision. One hundred and sixty (160) copies of questionnaire were administered in Islamabad stock exchange, while regression analysis was used to find out the effect of representativeness bias on investment decision. Their results showed that investors were affected by representativeness bias in Islamabad Stock Exchange and the investors in Islamabad are using past performance as the representatives of the future [9].

Sohail, Rehman, and Javid empirically examined the short term under and overreaction effect in Karachi Stock Exchange, Pakistan, with regards to 2008 global financial crisis from September 2007 to 2009. Stock price, trading volume and KSE 100 index were obtained and the results showed that there is evidence of significant overreaction in the first two weeks and significant under- reaction in the 12th and 24th week in the financial sector. For the non-financial sector, the returns stayed positive and insignificant for both the winner and loser portfolios, thereby negating any evidence of significant overreaction [18].

Effects of investors' herd behavior on stock market reactions of listed companies in Kenya was studied by [4]. Focused was on effect of investors' loss aversion, investors' mental accounting and investors' overconfidence on stock market reactions of listed companies in Nairobi Securities Exchange, Kenya for 2004 to 2016. Their study made used of secondary data, panel regression analysis model was used and their results indicated that herd behavior did not have a significant effect on stock market reaction. However, loss aversion, mental accounting and overconfidence had significant effect on stock market reaction in Nairobi Securities Exchange, Kenya.

\section{Methodology}

The study made used of cross-sectional research designs. Two hundred and twenty-one (221) copies of a structured questionnaire was administered to registered dealing members out of the two hundred and sixty-two (262) registered dealing members in Lagos State. Random sampling technique was used in the selection of dealing members. The sample size was arrived at by using Yamane formula [24] and also making provisions for questionnaires that were not returned and those dealing members that were not reached. The sample size represented $84 \%$ of the sampled population. This sample size showed a high representation of the population, therefore, decision reached can be generalised.

\subsection{Validity and Reliability of Survey Instrument}

Content validity was used for the survey instrument. The questionnaire was given to the researcher's supervisors and experts in the field of finance to check if the content of the research instrument evaluated the subject matter. They all reviewed and gave their opinion on all the items in the survey regarding their merit in assessing indices of market conditions. Research instrument is said to be valid if it measures what is intended to be measured [19].

In determining the reliability of the research instrument, the completed copies of questionnaire were analysed for reliability using the Cronbach Alpha reliability test $(\alpha)$. The alpha $(\alpha)$ reliability is 0.808 for stock market conditions, therefore, the instrument was $80.8 \%$ reliable. According to Tavakol and Dennick, a Cronbach alpha test between 0.70 and 0.95 is an acceptable reliability test for the research instrument [21].

\subsection{Data Description}

The data used were sourced through survey using a structured questionnaire. The questionnaire was articulated and contained closed-ended multiple-choice questions. The questions in the questionnaire required the respondents to tick their choices among options provided. The questions were structured using the five-point Likert rating scales ranging from strongly agree (5) to strongly disagree (1). Out of the two hundred and twenty-one (221) copies of questionnaire distributed, one hundred and seventy-eight (178) were returned which made it $80.5 \%$ of the sampled population, while only one hundred and sixty-eight (168) respondents filled the biographic section. Descriptive statistics was used to present the opinion of investors regarding the market conditions, while Chi-square $\left(\chi^{2}\right)$ was used to determine if stock market conditions have any influence on investors' reactions.

\section{Results}

\subsection{Biographic Data}

The background information of the respondents was 
presented in this section. The biographic data were gotten from the first section of the questionnaire. It was deduced from the analysis on Table 1 that majority of the respondents who filled the questionnaire were in the top positions and were knowledgeable in the stock market. This analysis also showed that majority of the respondents were well educated and had what it took to fill the questionnaire given their level of education. Considering the saying that "experience is the best teacher", Table 1 also showed that most of the respondents had experience in the stock market with respect to their length of service and had a good knowledge on how to trade. Thereafter, it was revealed that majority of the respondents were not "new comers" in the stock market, rather they were strong players considering the number of years of trading in the stock market and the experience gathered for those number of years. Finally, the result showed that majority of the firms did not need so many staff, rather few, but well experienced due to nature of job carried out by the dealing members

Table 1. Biographic Data of Respondents.

\begin{tabular}{|c|c|c|}
\hline & Number & Percentage (\%) \\
\hline \multicolumn{3}{|l|}{ Respondents' Position } \\
\hline Director & 22 & 13 \\
\hline Manager & 112 & 67 \\
\hline Dealer & 12 & 7 \\
\hline Officer & 22 & 13 \\
\hline Total & 168 & 100 \\
\hline \multicolumn{3}{|c|}{ Educational Qualification } \\
\hline Below First Degree & 2 & 1 \\
\hline First Degree & 44 & 26 \\
\hline Masters Degree & 120 & 73 \\
\hline Total & 168 & 100 \\
\hline \multicolumn{3}{|l|}{ Length of Service } \\
\hline Below 10 years & 38 & 23 \\
\hline $10-20$ years & 104 & 62 \\
\hline $21-30$ years & 22 & 13 \\
\hline Above 30 years & 4 & 2 \\
\hline Total & 168 & 100 \\
\hline \multicolumn{3}{|c|}{ Duration in the Stock Market } \\
\hline Below 10 years & 26 & 15 \\
\hline $10-20$ years & 78 & 45 \\
\hline $21-30$ years & 54 & 32 \\
\hline Above 30 years & 12 & 7 \\
\hline Total & 168 & 100 \\
\hline \multicolumn{3}{|l|}{ Staff Strength } \\
\hline Below 150 & 166 & 99 \\
\hline $151-200$ & 2 & 1 \\
\hline $201-250$ & 00 & \\
\hline Above 250 years & 0 & 0 \\
\hline Total & 168 & 100 \\
\hline
\end{tabular}

\subsection{Descriptive Statistics}

The mean responses of opinion of respondents on conditions around the stock market were presented on Table 2. For decision making, a standard of the mid-point (i.e. 3.00) was used as a hypothetical cut-off point, obtained by adding the exact upper limit and exact lower limit of the scale and divided by two, that is $5.5+0.5=6.00 / 2=3.00$. In the analysis, any variable with the mean score of 3.00 and above was considered agreed upon.; while any variable with the mean score less than 3.00 was considered disagreed upon.

Return on investment (B4) had the highest mean value of 4.57, while volume of transaction (B5) with 3.37 had the lowest. This showed a true position of investors' reaction in the stock market because every investor major aim is to make more returns on investment. The mean values presented in Table 2 showed that the mean responses of the respondents to variables one to ten are greater than 3.0, therefore, it depicted that majority of the respondents used for this study averagely agreed with these variables as related to the stated and coded market conditions.

Table 2. Respondents' Reactions to Stock Market Conditions.

\begin{tabular}{lll}
\hline Variables & Mean & Rank \\
\hline B4= Return on investment & 4.57 & 1 \\
B1= Availability of information & 4.44 & 2 \\
B9= Interest rate & 4.29 & 3 \\
B10= Government policy statement & 4.29 & 4 \\
B3= Risk associated with a stock & 4.05 & 5 \\
B6= Stock market liquidity & 4.03 & 6 \\
B8= Exchange rate & 4.03 & 7 \\
B2= Arbitrage due to excessive price volatility & 3.99 & 8 \\
B7= Emergence of insider trading & 3.49 & 9 \\
B5= Volume of transaction & 3.37 & 10 \\
\hline
\end{tabular}

\subsection{Chi-square $\left(\chi^{2}\right)$ Results}

The results of the relationship between conditions around the stock market and investors' reaction were summarised below:

$$
\begin{aligned}
& \text { B1: } \chi^{2}(4)=238.74, \mathrm{P}<0.05 \mathrm{~B} 6: \chi^{2}(4)=144.53, \mathrm{P}<0.05 \\
& \text { B2: } \chi^{2}(4)=108.12, \mathrm{P}<0.05 \mathrm{~B} 7: \chi^{2}(4)=30.82, \mathrm{P}<0.05 \\
& \mathrm{~B} 3: \chi^{2}(4)=132.22, \mathrm{P}<0.05 \mathrm{~B} 8: \chi^{2}(4)=144.53, \mathrm{P}<0.05 \\
& \text { B4: } \chi^{2}(4)=307.56, \mathrm{P}<0.05 \mathrm{~B} 9: \chi^{2}(4)=175.76, \mathrm{P}<0.05 \\
& \text { B5: } \chi^{2}(4)=27.96, \mathrm{P}<0.05 \mathrm{~B} 10: \chi^{2}(4)=193.91, \mathrm{P}<0.05
\end{aligned}
$$

The critical value of chi-square of degree of freedom 4 at 0.05 level of significance was 9.488 . The summarised results above revealed that all the values of chi-square computed at the different conditions around the market were greater than the critical value, therefore, stock market conditions influenced investors' reactions. This asserted that when the different market conditions such as price volatility, arbitrage, government policy statements, etc took place, they influenced the manner in which investors took decision. Therefore, the purchase or sale of stocks were determined by these stock market conditions.

\section{Conclusion}

This study had shown empirical evidences in support of the relationship between the conditions around the stock market and reactions from investors. In the stock market, it is theoretically believed that the presence of the different market conditions would influence investors' reactions. From the results of this study, it was concluded that the reactions of investors are related to the different conditions around the stock market. This means that when these conditions occurred, investors tend to react by either buy or sell which may not be a decision that should have been taken at that 
particular point in time. The study recommended that relationship of the stock market conditions and investors' reaction should be put in check by all investors because immediate reaction to every conditions that affect the market could lead to massive loss of investments. Before reacting to a condition in the market, a detailed investigation and analysis should be conducted.

\section{References}

[1] AlKhars, M., Evangelopoulos, N., Pavur, R. \& Kulkarni, S. (2019). Cognitive biases resulting from the representativeness heuristic in operations management: An experimental investigation. Psychology Research and Behavior Management, 12: 263-276.

[2] Barberis, N., \& Huang, M. (2001). Mental Accounting, Loss Aversion and Individual Stock Returns. The Journal of Finance, 56 (4): 1247-1292.

[3] Barberis, N., \& Thaler, R. (2003). A survey of behavioral finance. In Constantinides, G., Harris, M., \& Stulz, R. (Eds.), Handbook of the Economics of Finance. Amsterdam: NorthHolland, p. 1077.

[4] Cherono. I., Olweny, T., \& Nasieku, T. (2019). Investor behavior biases and stock market reaction in Kenya. Journal of Applied Finance \& Banking, 9 (1): 147-180.

[5] Clark, W. A. V. \& Lisowski, W. (2017). Prospect Theory and the Decision to Move or Stay. Retrieved on April 24, 2019 from https://www.pnas.org/content/pnas/114/36/E7432.full.pdf.

[6] Fogel, O., \& Berry, T. (2006). The disposition effect and individual investor decisions: The roles of regret and counterfactual alternatives. Journal of Behavioral Finance, 7 (2): $107-116$.

[7] Folkinshteyn, D., Meric, G., \& Meric, I. (2015). Investor reaction in stock market crashes and post-crash market reversals. The International Journal of Business and Finance Research, 9 (5): 57-70.

[8] Ganesh, R. and Naresh, G. (2016). Industry herding behaviour in India stock market. American Journal of Finance and Accounting, 4 (3-4): 284-308.

[9] Irshad, S., Badshah, W. \& Hakam, U. (2016). Effect of representativeness bias on investment decision making. Management and Administrative Sciences Review, 5 (1): 2630 .

[10] Kahneman, D. and Tversky, A. (1979). Prospect theory: an analysis of decision under risk. Econometrica, 47 (2): 263 292.

[11] Kim C., Lee W., Choi, Y. H. and Ahn, J. Y. (2013). Analyzing herd behaviour in global stock markets: An intercontinental comparison. Retrieved February 23, 2015 from http://arxiv.org/pdf/1308.3966.pdf.

[12] Lehenkari, M., \& Perttunen, J. (2004). Holding onto the losers: finish evidence. The Journal of Behavioral Finance, 5 (2): 116-126.

[13] Mahmoudi, V., Shirkavand, S., \& Salari, M. (2011). How do investors react to the earnings announcement? International Research Journal of finance \& Economics, 70 (1): 145-152.

[14] Ngoc, L. T. B (2014). Behavior pattern of individual investors in stock market. International Journal of Business and Management, 9 (1): 1-16.

[15] Oh, W. \& Kim, J. (2001). The effects of firm characteristics on investor reaction to it investment announcements. $22^{\text {nd }}$ International Conference on Information System, Retrieved on May 17, 2019 from http://aisel.aisnet.org/icis2001/, 145-156.

[16] Ouarda, M., Abdelfatteh, E. B. and Olivero, B. (2013). Herding behaviour under markets condition: Empirical evidence on the European financial markets. International Journal of Economics and Financial Issues, 3 (1): 214-228.

[17] Ritter, J. R. (2003). Behavioral Finance. Pacific-Basin Finance Journal, 11 (4): 429-437.

[18] Sohail, A., Rehman, M., \& Javid, A. (2017). Stock market reactions on returns and trading volume: the impact of the global financial crisis. Revista Evidenciação Contábil \& Finanças, 5 (1): 132-151.

[19] Taherdoost, H. (2016). Validity and reliability of the research instrument: how to test the validation of questionnaire/survey in a research. International Journal of Academic Research in Management, 5 (3): 28-36.

[20] Tan, L., Chiang, T., Mason, J. and Nelling, E. (2008). Herding behaviour in Chinese stock markets: An examination of A and B shares. Pacific-Basin Finance Journal, 16 (1): 61-77.

[21] Tavakol, M. and Dennick, R. (2011). Making sense of Cronbach's alpha. International Journal of Medical Education, 2 (1), 53-55.

[22] Tran, N. M. and Huy, H. T. (2011). Herding behaviour in an emerging stock market: empirical evidence from Vietnam. Research Journal of Business Management, 5 (2): 51-76.

[23] Waweru, N. M., Munyoki, E., \& Uliana, E. (2008). The effects of behavioral factors in investment decision-making: a survey of institutional investors operating at the Nairobi Stock Exchange. International Journal of Business and Emerging Markets, 1 (1): 24-41.

[24] Yamane, Y. (1967). Statistic: An introductory analysis, Second Edition, New York, Harpen and Row Publishing Limited

[25] Yang, Z. H., Liu, J. G., Yu, C. R., \& Han, J. T. (2017) Quantifying the effect of investors' attention on stock market. PLoS ONE 12 (5): Retrieved on May 17, 2019 from https://doi.org/10.1371/journal.pone. 0176836. 